\title{
FATWA SATWA \\ (KAJIAN FIQH DAN HUKUM POSITIF TENTANG PERBURUAN \\ SATWA)
}

\author{
Oleh : \\ 1. Dr. Fachrurazi, S.Ag,. M.M (ferry.7co@gmail.com) \\ 2. Yusuf, M.HI (you_shop@yahoo.co.id)
}

\begin{abstract}
Hunting animals is a strategy of gaining food to survive. This activity is not only done by traditional people but also done by modern ones, yet they have different techniques and tools for hunting. Islam has rules for such activity (ash-shoid) according to Al-Quran, Hadith, Ijma, and Qiyas. Besides, Indonesian government regulates the activity through an act number 5 of 1990 about natural souces and ecosystem conservation. The resuts of reseach show that according to sharia, hunting is intended to fulfil human's need for food but by avoiding haraam preys in order to obey the alminghty Allah. Meanwhile, Indonesian government regulates hunting activity through an act number 13 of 1994. Even though sharia and the act of hunting have some differences but both rules show that Islam and Indonesian govement have common perceptions in which animals may be hunted for food and other purposes but they must be protected from over exploitation. Therefore, according to Islamic context, human as khalifah fil ardh and as good Indonesian citizen should follow the rules to maintain the balance life cycle.
\end{abstract}

Keywords : Prey, Hunting Place, Hunting Season, Hunter, Hunting Tools.

\begin{abstract}
Abstrak
Berburu binatang (satwa) merupakan salah satu cara untuk memenuhi kebutuhan hidup manusia. Aktifitas berburu ini bukan hanya dilakukan oleh manusia zaman dahulu saja, tetapi juga tetap dilakukan hingga zaman sekarang. Yang berbeda hanya cara yang dilakukan, alat dipergunakan, dan berbagai ragam binatang dijadikan buruan. Islam memberikan tata aturan (hukum) yang berhubungan dengan perburuan (ash-shoid) dengan bersumber dari al-Qur'an dan al-Hadis, ditambah dengan Ijma` dan Qiyas (fiqh). Hukum positif Indonesia juga mengatur hal-hal yang berkaitan dengan berburu melalui Undang-undang Nomor 5 Tahun 1967 tentang Ketentuan-ketentuan Pokok Kehutanan dan Undang-undang Nomor 5 Tahun 1990 tentang Konservasi Sumber Daya Alam Hayati dan Ekosistemnya. Hasil penelitian ini menyimpulkan bahwa Hukum Islam perlu mengatur perburuan agar manusia mendapatkan yang terbaik dalam hal makanan dan untuk menguji manusia dalam hal ketatan kepada Allah SWT. Demikian juga dalam hukum
\end{abstract}


positif, peraturan Pemerintah No.13 Tahun 1994 tentang Perburuan Satwa Buru menjadi dasar hukum dalam kegiatan berburu di Indonesia. Walaupun antara kedua aturan tersebut (hukum Islam dan Hukum Positif) terdapat beberapa perbedaan, namun keduanya juga mempunyai beberapa bentuk persamaan yang menunjukkan bahwa agama (Islam) dan negara ini mempunyai semangat yang sama bahwa satwa merupakan salah satu entitas yang ada di dunia ini yang walaupun dalam beberapa hal boleh dimanfaatkan oleh manusia (makan, menunggangi, dan lain-lain) namun bukan berarti harus dieksploitasi sehingga mengancam eksistensi dan ekosistem dari satwa tersebut. Maka oleh sebab itu lah, dalam konteks Islam manusia sebagai khalifah fil ardh, Islam dengan fiqh-nya dan negara dengan hukumnya, perlu mengatur hal-hal yang berkaitan dengan perburuan satwa demi menjaga siklus kehidupan di dunia ini bisa berjalan seimbang.

Kata Kunci : satwa buru, tempat buru, musim buru, pemburu dan alat berburu

\section{A. Pendahuluan}

Dalam memenuhi kebutuhan hidupnya, manusia melakukan beberapa usaha. Salah satu di antaranya adalah berburu binatang untuk memenuhi kebutuan dasar manusia yaitu pangan. Berburu sudah dilakukan manusia sejak zaman dahulu hingga zaman sekarang. Berbagai macam cara dilakukan, bermacam-macam alat dipergunakan, dan berbagai ragam binatang dijadikan buruan.

Seiring dengan berjalannya waktu, baik itu cara, alat, dan hewan buruan mempunyai aturan yang berbeda-beda menurut masa maupun tempat. Aturan-aturan tersebut dibuat berdasarkan tujuan dalam perburuan. Ada yang berburu untuk memenuhi kebutuhan pangan, ada yang berburu hanya untuk menyalurkan hobi, ada juga untuk berolahraga, dan ada juga perburuan dilakukan untuk membasmi binatang yang menjadi hama, seperti: babi, tikus dan gajah yang merusak tanaman pertanian dan perkebunan manusia. Demikian pula pembuat aturan-aturan tersebut berasal dari berbagai macam tata hukum yang ada, misalnya tata hukum Indonesia atau hukum positif dan tata hukum Islam. Dalam Islam, manusia ditempatkan sebagai makhluk 
terbaik yang dilengkapi dengan aturan-aturan ${ }^{1}$. Peraturan yang dibuat dan disepakati bersama tersebut, kemudian disebut hukum. Inspirasi atau cantolan peraturan tersebut umumnya bersumber dari wahyu Allah dan rasulnya, bahkan ada juga yang berasal dari ijtihad ulama. Hukum Allah tercantum di dalam al-Qur`an dan al-Hadis. Selanjutnya manusia memahami dan melaksanakan hukum-hukum tersebut. Namun, dalam beberapa hal, hukumhukum tertentu tidak diterangkan secara rinci, sehingga manusia melakukan ijtihad dengan bersumber dari al-Qur`an dan al-Hadis, ditambah dengan Ijma` dan Qiyas, sebagai bukti bahwa manusia adalah khalifah Allah di muka bumi.

Diantara salah satu dari hukum tersebut adalah hukum perburuan binatang. Al-Qur`an menerangkan tentang halal dan haramnya binatang, boleh tidaknya berburu, serta alat yang digunakan untuk berburu. ${ }^{2}$ Sementara dalam al-Hadis juga diterangkan halal-haramnya binatang, binatang yang boleh diburu, serta alat-alat yang boleh digunakan untuk berburu.

Al-Qur'an dan Hadits memberikan legitimasi kebolehan umatnya untuk berburu disertai dengan syarat-syarat. Hal ini penting diatur karena banyak dari manusia menggantungkan hidupnya dari berburu. ${ }^{3}$ Bahkan ahliahli fiqh pun kemudian membuat tersendiri bab tentang berburu, dengan menguraikan mana yang halal dan mana yang haram, mana yang wajib dan mana yang sunnah.

Hukum positif Indonesia merasa penting untuk mengatur hal-hal yang berkaitan dengan berburu, selain membolehkan untuk berburu, hukum perburuan langsung dikaitkan dengan masalah melestarikan kekayaan alam. Sebagaimana tercantum dalam penjelasan umum PP No. 13 Tahun 1944 diterangkan, bahwa bangsa Indonesia dikaruniai oleh Tuhan Yang Maha Esa

${ }^{1}$ Dalam Q.S. At-Tiin (95): 4-6 diterangkan, bahwa manusia diciptakan sebaik-baiknya, kemudian dikembalikan kepada serendah-rendahnya, kecuali orang-orang yang beriman dan beramal sholeh sebagai wujud adanya aturan dalam hidup ini.

${ }^{2}$ Lihat QS Al-Maidah (5): 1, 2,4,94,96

3 Yusuf al-Qardawi, Halal dan Haram dalam Islam, alih bahasa Mu`ammal Hamidy, (Surabaya: Bina Ilmu, 1982), 82.

${ }^{4}$ Presiden R.I, Peraturan Pemerintah No. 13 Tahun 1994 Tentang Perburuan Satwa Buru, www.menlh.go.id. 149. 
tanah air yang kaya dengan sumber daya alam hayati dan ekosistemnya, antara lain satwa yang beraneka ragam jenisnya.

Untuk melestarikan kekayaan alam yang berupa satwa liar tersebut, Undang-undang Nomor 5 Tahun 1967 tentang Ketentuan-ketentuan Pokok Kehutanan dan Undang-undang Nomor 5 Tahun 1990 tentang Konservasi Sumber Daya Alam Hayati dan Ekosistemnya menetapkan antara lain bahwa pemanfaatan satwa liar dapat dilaksanakan dalam bentuk perburuan, dan pelaksanaannya perlu diatur dengan peraturan perundang-undangan dengan mengindahkan tujuan yang telah ditetapkan dalam Undang-undang tersebut.

\section{B. Perburuan Satwa dalam Konsepsi Fiqh}

Di dalam kitab-kitab fiqh pembahasan perburuan satwa popular dengan istilah الصيد yang secara bahasa diartikan sebagai binatang yang diburu sebagaimana yang tercantum dalam kitab-kitab fiqh. ${ }^{5}$ Secara terminologi ada beberapa pengertian dari الصيد, diantaranya Abd ar-Rahman al-Jazairy menerangkan bahwa Ash-Shaid adalah apa-apa yang diburu dari hewan yang bisa dimakan dengan ketentuan dan syarat yang akan ditentukan ${ }^{6}$. Sedangkan Abu Bakar Jabir al-Jazairi mendefinisikan Ash-shaid merupakan hewan buruan yaitu hewan darat yang liar dan hewan air berupa ikan ${ }^{7}$.

Dari kedua definisi tersebut, dapat diambil kesimpulan bahwa kata Ash-shaid lebih sering diartikan sebagai buruan atau hewan yang diburu. Kemudian buruan yang yang dimaksud adalah hewan liar yang halal dimakan dan tujuan dari perburuan itu adalah untuk dimakan. Namun demikian,

5 A.W. Munawwir, Kamus al-Munawwir Arab-Indonesia Terlengkap, cet. XIV (Surabaya: Pustaka Progressif, 1997), 806.

${ }^{6}$ Abd ar-Rahman al-Jazairy, Kitab al-Fiqh 'Ala al-Mazahibi al-'Arba`ah, cet. I (Beirut: Daru al-Fikr, 1996), II: 22

${ }^{7}$ Abu Bakr Jabir al-Jazairy, Minhaj al-Muslim, (Beirut: Dar al-Fikr, 1992), 497 
perburuan satwa bisa diartikan sebagai suatu kegiatan berburu satwa atau hewan yang biasa diambil manfaatnya baik itu satwa darat, air maupun udara yang berlaku syarat-syarat bagi hewan atau satwa buru, pemburu dan alat yang digunakan untuk berburu yang hewan tersebut halal untuk dimakan tanpa harus disembelih. Jadi yang membedakan antara perburuan dan penyembelihan adalah bahwa penyembelihan berarti hewan yang halal untuk dimakan harus disembelih terlebih dahulu sedangkan perburuan hewan tersebut tanpa harus disembelih halal untuk dimakan dengan syarat-syarat yang akan diterangkan kemudian.

Konsensus ulama menyatakan bahwa hukum asal perburuan adalah mubah dan hukum asal buruan adalah halal ${ }^{8}$. Sedangkan Imam Malik memakruhkan perburuan satwa apabila tujuannya adalah israf (berlebihlebihan). Abdrrahman Juzairy ${ }^{9}$ mengharamkan perburuan satwa apabila menyebabkan kerusakan bagi pertanian, kekacauan bagi tempat tinggal dan tujuan perburuan adalah senang-senang dan main-main. Selanjutnya ulama Muta`akhkhirin dari mazhab Maliki memperinci dan memilah-milah bahwa bagi sebagian manusia hukum berburu adalah wajib, demikian juga bagi sebagian manusia hukumnya mandub dan bagi sebagian manusia lainnya adalah makruh bahkan haram hukumnya bagi sebagian manusia ${ }^{10}$. Kemudian Jumhur ulama juga sepakat bahwa perburuan satwa darat hukumnya haram bagi muhrim haji ${ }^{11}$. Pendapat para ulama tersebut sejalan dengan ayat-ayat Al-Qur'an dan Hadits. ${ }^{12}$

Dari dalil hadits, ada 2 hadis yang sering kali dijadikan dasar hukum dari perburuan satwa, yaitu :

${ }^{8}$ Ibn Rusyd al-Hafid, Bidayah al-Mujtahid wa Nihayah al-Muqtasid, (Surabaya: Toko Kitab al-Hidayah, tt), 332

${ }^{9}$ Abd ar-Rahman al-Jazairy, Kitab al-Fiqh, II: 23

${ }^{10}$ Ibn Rusyd al-Hafid, Bidayah al-Mujtahid, 332

${ }^{11}$ Abu Bakr Jabir al-Jazairy, Minhaj al-Muslim, (Beirut: Dar al-Fikr, 1992), 497

${ }^{12}$ Lihat QS Al-Maidah (5): 96, 2, 4. 


$$
\begin{aligned}
& \text { سألت رسول الله ص.م قلت أنا قوم نصيد بهذه الكلب فقال إذا أرسلت كلابك المعلمة وذكرت } \\
& \text { اسم الله عليها فكل مما أمسكن عليك و إن قتلن الا أن يأكل الكلب فإن أكل فلا تأكل فإنى } \\
& \text { أخاف أن يكون انما أمسك على نفسه وإن خالطها كلاب من غيرها فلا تأكل } 13 \\
& \text { سـألت رسـول الله ص.م. عـن صسيد المعـراض, فقــال: إذا أصـاب بحـده فكلـ, وإذا } \\
& \text { أصاب بعرضه فقتل فإنه وقيذ فلا تأكل.14 }
\end{aligned}
$$

Secara garis besar hewan yang boleh diburu dikelompokkan menjadi dua, yaitu: hewan air dan hewan darat, termasuk burung-burung. Hewan air halal hukumnya meskipun sudah menjadi bangkai. Ditinjau dari tujuan perburuan, hewan buruan dibagi menjadi dua yaitu hewan yang diburu untuk dimakan dan yang tidak untuk dimakan ${ }^{15}$.

Selanjutnya, para pemikir hukum Islam (Fuqaha') menyatakan bahwa seseorang diperbolehkan menjadi pemburu yang hewan buruannya halal apabila memenuhi syarat-syarat sebagai berikut ${ }^{16}$ :

1) Pemburu adalah seorang muslim atau ahli kitab. Halalnya buruan ahli kitab dengan syarat ketika melempar alat berburu tidak menyebut nama selain Allah seperti: salib ataupun Yesus dan tidak disyaratkan tasmiyah dalam hukum ahli kitab.

2) Pemburu adalah seorang balig dan berakal.

3) Pemburu bukanlah seorang muhrim haji dengan klasifikasi hewan buruannya adalah hewan darat, namun apabila hewan air maka halal buruannya dan pemburu tersebut tidak terkena sanksi. ${ }^{17}$.

4) Pemburu harus berniat berburu sebelum melakukan perburuan. Dan apabila seseorang melemparkan senjatanya sembarangan dan mengenai hewan maka hewan tersebut tidak halal dimakan.

\footnotetext{
${ }^{13}$ Muslim, Sahih Muslim, Kitab as-Saidi wa al-Zabaih, (ttp: tp, tt), II: 165. Hadis riwayat dari 'Adi ibn Hatim

${ }^{14}$ Ibid.

${ }^{15}$ Abd ar-Rahman al-Jazairy, Kitab al-Fiqh, II: 25

${ }^{16}$ Abd ar-Rahman al-Jazairy, Kitab al-Fiqh, II: 27

${ }^{17}$ Ibn Rusyd al-Hafid, Bidayah al-Mujtahid, 338
} 
5) Pemburu ketika melemparkan alat buru harus menyebut nama Allah (tasmiyah).

6) Pemburu apabila menggunakan alat buru berupa hewan pemburu, maka hewan tersebut harus benar-benar dia yang melepaskannya dan memerintahkannya untuk berburu dan pemburu tersebut telah berniat dan menyebut nama Allah.

Selain mengatur tentang orang yang berhak menjadi pemburu hewan, ulama fiqh juga mengatur tentang alat yang boleh dipakai untuk berburu. Alat untu berburu ada dua macam yaitu yang berupa benda dan berupa hewan pemburu. Alat buru yang berupa benda juga dibagi menjadi dua yaitu benda tajam dan benda tidak tajam. Demikian juga hewan pemburu ada yang berupa anjing dan sejenisnya seperti harimau dan singa serta hewan pemburu yang berupa burung-burung seperti elang dan rajawali $^{18}$.

a. Alat berburu yang berupa benda.

Sebagaimana disebutkan sebelumnya, alat berburu yang berupa benda ada dua macam benda tajam dan benda tidak tajam ${ }^{19}$.

1) Alat berburu yang berupa benda tidak tajam.

Alat berburu yang berupa benda tidak tajam contohnya batu dan tongkat. Dalam fiqh para ulama mempunyai tiga pendapat yang berbeda yaitu:

a) Sebagian membolehkan tapi harus dengan disembelih apabila didapati masih hidup. Dan jika hewan buruan mati karena benda tadi tanpa disembelih maka hewan buruan tidak halal.

b) Sebagian membolehkan secara mutlak.

c) Sebagian lagi membedakan antara yang bisa melukai karena bisa mengeluarkan darah hewan buruan dengan yang tidak bisa mengeluarkan darah. Maka apabila hewan buruan terluka ia menjadi halal dan apabila tidak maka hewan buruan haram.

\footnotetext{
${ }^{18}$ Abd ar-Rahman al-Jazairy, Kitab al-Fiqh, II: 33

${ }^{19}$ Ibn Rusyd al-Hafid, Bidayah al-Mujtahid, 333.
} 
Pendapat ini berdasar pada sifat dari alat buru melukai hewan buruan bukan pada bentuk alat berburu.

\section{2) Alat berburu dari benda tajam.}

Syarat-syarat bagi alat berburu yang berupa benda tajam yaitu ${ }^{20}$ :

a) Alat buru yang harus mengenai hewan buruan adalah bagian tajamnya bukan bagian tumpulnya.

b) Alat tersebut harus melukai hewan buruan dan mengeluarkan darahnya.

c) Tidak boleh adanya sebab kematian lain selain senjata tajam.

b. Alat berburu yang berupa hewan pemburu.

Alat berburu yang berupa hewan mempunyai syarat-syarat bagi halalnya hewan buruan yaitu ${ }^{21}$ :

1) Hewan pemburu tersebut harus terlatih.

a) bukti terlatih bagi hewan pemburu yang berupa anjing singa dan harimau yaitu:

(1) apabila dipanggil tuannya ia akan menjawab

(2) apabila disuruh berburu ia beragkat berburu

(3) apabila dicegah dia akan tercegah atau diam di tempat. Untuk syarat yang ketiga tidak berlaku bagi singa, harimau dan semacamnya.

b) bukti terlatih bagi hewan pemburu yang berupa burung yaitu:

(1) apabila dipanggil tuannya dia akan menjawab

(2) apabila diperintah untuk berburu dia akan berangkat berburu.

2) Tidak memakan bagian dari hewan buruan. Maka apabila hewan buruan telah dimakan sebagiannya maka tidak halal.

3) Harus melukai hewan buruannya. Maka apabila hewan pemburu membunuh hewan buruannya dengan cara membanting, mencekik,

${ }^{20}$ Abd ar-Rahman al-Jazairy, Kitab al-Fiqh, II: 33.

${ }^{21}$ Ibid.,. 35 
melemparkannya ataupun menindihya dengan berat tubuhnya maka hewan tersebut tidak halal.

Dalam kitab-kitab fiqh, pembahasan tentang sanksi dan atau akibat hukumnya apabila melanggar syarat-syarat yang berkaitan dengan perburuan tidak dibahas dalam sub-bab khusus. Namun demikian, dalam hukum Islam, apabila syarat-syarat tidak dipenuhi maka hukumnya adalah batal dan apabila batal maka hewan buruan tidak halal untuk dimakan. ${ }^{22}$

\section{Perburuan Satwa dalam Konsepsi Hukum Positif}

Secara bahasa Perburuan bermakna: 1. hal berburu, 2. tempat berburu. Perburuan berasal dari kata dasar buru yang anonimnya adalah berburu mempunyai arti: mencari atau mengejar binatang dalam hutan dan sebagainya. ${ }^{23}$

Sementara menurut istilah, perburuan adalah segala sesuatu yang bersangkut paut dengan kegiatan berburu ${ }^{24}$. Dan berburu adalah menangkap dan atau membunuh satwa buru yang termasuk mengambil atau memindahkan telur-telur dan atau sarang satwa buru ${ }^{25}$.

Definisi "satwa" menurut Pasal 1 butir 5 Undang-undang nomor 5 Tahun 1990 adalah sebagai berkut:

"Satwa adalah semua jenis sumber daya alam hewani, baik yang hidup di darat maupun yang hidup di air"

Sementara definisi "satwa liar" dimuat dalam Pasal 1 butir 7 yaitu sebagai berikut:

"Satwa liar adalah semua binatang yang hidup di darat, dan atau di air dan atau udara yang masih mempunyai sifat-sifat liar, baik yang hidup bebas maupun yang dipelihara oleh manusia"

${ }^{22}$ Abu Bakr Jabir al-Jazairy, Minhaj, 321

${ }^{23}$ Peter Salim dan Yenny Salim, Kamus Bahasa Indonesia Kontemporer, edisi. 1, (Jakarta: Modern English Press, 1991),

${ }^{24}$ Peraturan Pemerintah No. 13 Tahun 1994 tentang perburuan Pasal 1 angka (2)

${ }^{25}$ Peraturan Pemerintah No. 13 Tahun 1994 tentang perburuan Pasal 1 angka (1) 
Kadang-kadang "binatang liar" didefinisikan dengan "binatang buas", tetapi sebenarnya hal tersebut tidak tepat karena tidak sama" binatang liar" termasuk "binatang buas". Hal yang sangat erat hubungannya dengan "satwa" adalah "habitat". Pengertian "habitat" menurut Undang-undang Nomor 5 Tahun 1990 Pasal 1 butir 8 adalah: Lingkungan tempat tumbuhan atau satwa dapat hidup dan berkembang secara alami.

Menurut Undang-undang Nomor 5 Tahun 1967, Satwa termasuk hasil hutan. Hal ini dimuat pada penjelasan Pasal 1 ayat (2) yang rumusannya adalah:

"Hasil hutan seperti satwa buru, satwa elok, dan lain-lain hewan serta bagian-bagiannya atau yang dihasilkannya."

Pasal 16 Undang-undang Nomor 5 Tahun 1967 membedahkan "satwa liar" atas 2 jenis yaitu: (1) Satwa liar tidak dilindungi. (2) Satwa liar dilindungi. Akan tetapi tampaknya Peraturan Pemerintah Nomor 28 Tahun 1985 tentang Perlindungan Hutan tidak memuat perlindungan tehadap satwa yang dilindungi secara lansung. Perlindungan satwa dimuat oleh Undang-undang Nomor 5 Tahun 1990. dengan demikian, Ordinansi Perlindungan Binatang Liar 1931 telah dicakup dalam Undang-undang Nomor 5 Tahun 1990.

Sesuai dengan salah satu asas dari asas-asas hukum pidana yaitu asas legalitas yang berbunyi: "Tidak ada perbuatan yang dilarang dan diancam dengan pidana jika tidak ditentukan terlebih dahulu dalam perundangan," 26 maka perburuan satwa adalah boleh karena belum atau tidak ada hukum yang melarang perburuan satwa. Kemudian dengan adanya PP. No. 13 Tahun 1994 tentang perburuan satwa buru, maka kegiatan berburu menjadi boleh dengan aturan-aturan di dalamnya yang apabila melanggar aturan tersebut dapat dimasukkan ke dalam perbuatan pidana. Hal ini sesuai juga dengan salah satu asas hukum pidana lainnya yaitu: Tidak dipidana jika tidak ada kesalahan. Jadi perburuan satwa tidak

${ }^{26}$ KUHP Pasal 1 ayat (1) 
dilarang namun ada peraturan-peraturan yang harus ditaati dalam kegiatan perburuan satwa buru, seperti yang diatur dalam PP. No. 13 Tahun 1994 yaitu yang berkaitan dengan satwa buru, tempat buru, musim buru, pemburu dan alat berburu

\section{Satwa Buru}

Satwa buru adalah jenis satwa liar tertentu yang ditetapkan dapat diburu ${ }^{27}$. Sebagaimana tercantum dalam pasal 3 ayat (1) satwa yang boleh diburu adalah satwa liar yang tidak dilindungi. Dan terdapat pengecualian, yaitu bahwa Menteri dapat menentukan satwa yang dilindungi sebagai satwa buru ${ }^{28}$. Satwa buru digolongkan menjadi tiga, yaitu: burung, satwa kecil dan satwa besar yang kesemuanya diatur oleh Menteri ${ }^{29}$. Dan jumlah satwa buru untuk setiap tempat ditentukan oleh Menteri berdasarkan keadaan populasi dan laju pertumbuhannya ${ }^{30}$.

\section{Tempat Buru}

Menurut PP. No. 13 Tahun 1994 pasal 6 ayat (1) bahwa tempat berburu ada 3, yaitu:

a. Taman Buru adalah kawasan hutan yang ditetapkan sebagai tempat diselenggarakan peburuan secara teratur ${ }^{31}$.

b. Areal Buru adalah areal di luar taman buru dan kebun buru yang di dalamnya terdapat satwa buru yang dapat diselenggarakan perburuan $^{32}$.

c. Kebun Buru adalah lahan di luar kawasan hutan yang diusahakan oleh badan usaha dengan suatu alas hak, untuk kegiatan berburu ${ }^{33}$.

\section{Musim Buru}

\footnotetext{
${ }^{27}$ Ibid angka (4)

${ }^{28}$ Pasal 3 ayat (2)

${ }^{29}$ Pasal 3 ayat (3) dan (4)

${ }^{30}$ Pasal 4

${ }^{31}$ Pasal 1 angka (5)

${ }^{32}$ Pasal 1 angka (8)

${ }^{33}$ Pasal 1 angka (6)
} 
Musim berburu ditentukan oleh Menteri Kehutanan dengan persyaratan yang digunakan untuk menentukan musim berburu, yaitu $^{34}$ :

1) Keadaan populasi dan jenis satwa buru

2) Musim kawin

3) Musim beranak atau bertelur

4) Perbandingan jantan dan betina

5) Umur satwa buru

Kemudian diatur juga dalam pasal 8 ayat (1) bahwa apabila terjadi ledakan populasi satwa liar yang tidak dilindungi sehingga menjadi hama maka dilakukan tindakan pengendalian dengan cara berburu.

\section{Alat Buru}

Alat yang diperbolehkan untuk digunakan dalam usaha perburuan satwa, yaitu ${ }^{35}$ :

a. Senjata api buru

b. Senjata angin

c. Alat Oberburu tradisional

d. Alat berburu lainnya yang penggunaannya disesuaikan dengan jenis satwa buru.

\section{Pemburu}

Dalam ketentuan umum P.P. No. 13 Tahun 1994 tentang perburuan satwa buru disebutkan bahwa pemburu adalah orang atau kelompok orang yang melakukan kegiatan berburu ${ }^{36}$. Dan sebelum melakukan perburuan pemburu harus memiliki Akta Buru ${ }^{37}$ dan Izin

\footnotetext{
${ }^{34}$ Pasal 7 ayat (1) dan (2)

${ }^{35}$ Pasal 9 ayat (1)

${ }^{36}$ Pasal 1 angka (3)

${ }^{37}$ Akta buru adalah akta otentik yang menyatakan bahwa seseorang telah memiliki atau menguasai kemampuan dan ketrampilan berburu satwa buru
} 
Buru $^{38}$. Kemudian pemburu mempunyai hak dan kewajiban serta ada pemburu khusus yaitu mereka yang ditugaskan oleh Menteri atau pejabat yang berwenang untuk berburu dan ada beberapa cara berburu yang dilarang. Diantara cara berburu yang dilarang adalah 1) Menggunakan kendaraan bermotor atau pesawat terbang sebagai tempat beranjak. 2) Menggunakan bahan peledak dan atau granat. 3) Menggunakan binatang pelacak. 4) Menggunakan bahan kimia. 5) Membakar tempat berburu. 6) Menggunakan alat lain untuk menarik atau menggiring satwa buru secara massal. 7) Menggunakan jerat atau penangkap dan lubang perangkap. 8) Menggunakan senjata api yang bukan untuk berburu. Namun cara tersebut yang dilarang diatas terdapat pengecualian untuk kepentingan penelitian yaitu pada point ke 3, point ke 6 dan point ke 7.

Segala jenis aturan dan ketetapan yang telah ditentukan oleh pemerintah untuk keperluan berburu tersebut didukung dengan sanksi pidana, yaitu :

1. KUHP pasal 502 ayat (1) dan (2) bagi pelanggaran terhadap izin atau pemburu yang berburu tanpa izin terjerat dengan pasal tersebut yaitu diancam denagn kurungan paling lama satu bulan atau denda paling banyak 200 rupiah serta satwa yang ditangkap atau ditembak serat perkakas dan senjata yang digunakan dapat dirampas.

2. Dalam kaitannya dengan perburuan satwa liar yang dilindungi sanksi pidana terdapat pada pasal 40 ayat(2) yang merupakan sanksi bagi pelanggaran dari pasal 21 ayat (2) UU. No. 5 Tahun 1990. Pasal 21 ayat (2) huruf a, b dan e berkaitan dengan perburuan yaitu: laranagn menagkp satwa liar yang dilindungi dalam keadaan hidup meupun mati dan larangan mengambil, merusak, memusnahkan telur dan atau sarang burung yang dilindungi. Dan pasal 40 ayat (2) menyebutkan bahwa pelanggar dari pasal 21 ayat (2) dapat dikenakan sanksi pidana

${ }^{38}$ Surat Izin Berburu adalah surat yang diberikan oleh Menteri atau pejabat yang ditunjuk olehnya, yang menyebut pemberian hak untuk berburu kepada orang yang namanya tercantum di dalamnya dan surat izin tersebut tidak dapat dipindah tangankan atau dipergunakan oleh orang lain 
berupa pidana penjara paling lama 5 tahun dan denda paling banyak seratus juta rupiah.

3. Sanksi bagi pengusaha taman buru yang tidak merehabilitasi kerusakan wajib membayar ganti rugi sesuai dengan berat dan intensitas kerusakan yang ditimbulkan. Dan diganti rugi tidak menghilangkan tuntutan pidana atau pelnggaran yang dilakukannya sesuai dengan peraturan perundangan yang berlaku. Hal ini tercantum dalam pasal 43 ayat (1) dan (2) PP. No. 13 Tahun 1994.

\section{Satwa, antara Fiqh dan Hukum Positif}

Islam sebagai agama yang haq dan bersifat universal mampu mengiringi umat dan membawa pada jalan yang diridhai Allah SWT. Aspek yang tercakup dalam Islam tidak hanya berisikan hablu minallah melainkan juga meliputi persoalan idologi, sosial, politik, hukum, ekonomi, budaya dan bahkan kelestarian lingkungan hidup. Lingkup yang demikian luas itu menyangkut segala aspek kehidupan manusia. Lingkungan hidup atau ekologi merupakan unsur-unsur yang akan mempenagaruhi hidup dan kehidupan, salah satu di antaranya bumi tempak berpijak atau bumi sebagai sumber mata pencaharian. Allah SWT menyediakan bumi ini untuk manusia, agar manusia dapat memanfaatkannya dengan sebaik-sebaiknya. ${ }^{39}$

Perburuan adalah salah satu usaha manusia untuk memenuhi salah satu kebutuhan pokok manusia yaitu makan. Oleh karenanya perburuan diperbolehkan namun disertai dengan syarat-syarat yang merupakan wujud adanya peraturan-peraturan bagi manusia untuk membedakannya dari makhluq lain.

Peraturan-peraturan tersebut bagi manusia mempunyai manfaat, baik di dunia maupun di akhirat. Dengan demikian pembahasan perburuan satwa dalam hukum Islam adalah membahas bagaimana agar hewan buruan tersebut halal dimakan dan baik bagi manusia yang selanjutnya

${ }^{39}$ Lihat QS Al-An'am (6): 165 
ditetapkan syarat-syaratnya, baik itu yang berkaitan dengan hewan yang diburu, pemburu dan alat yang digunakan untuk berburu.

Berpacunya teknologi seiring dengan tumbuhnya industri yang membutuhkan sumber alam yang langka (terbatas) telah meninggalkan dampak atau implikasi kerugian bagi umat manusia sekarang dan genarasi yang akan datang. Pengurasan sumber alam, yang termasuk di dalamnya adanya perburuan satwa illegal secara besar-besaran adalah merupakan indikator adanya kehancuran kelestarian lingkungan hidup (ekosistem), yang didukung dengan adanya kemajuan teklnologi-yakni ditandai dengan semakin banyak dan efektifnya alat-alat canggih yang dapat digunakan dalam berburu binatang satwa.

Secara umum perbruan satwa diatur dalam PP. No. 13 Tahun 1994 yang kemudian hal-hal yang bersifat teknis diatur dan ditentukan oleh Menteri yang berwenang. Dalam PP. No. 13 Tahun 1994 diatur tentang satwa buru, tempat dan musim buru. Kemudian syarat-syarat yang berlaku bagi pemburu dan termasuk di dalamnya hak dan kewajiban bagi pemburu serta cara apa saja yang tidak diperbolehkan dalam berburu. Diatur juga apa, siapa dan bagaimana mengelola taman buru dan kebun buru.

Hingga dititik ini, antara hukum Islam dan hukum positif mempunyai semangat yang sama terkait dengan perburuan satwa, hal-hal yang menjadi persamaan adalah :

\section{a) Dari Segi Pengertian}

Dalam hukum Islam meskipun الصبيد diartikan sebagai buruan tapi yang dibahas meliputi hewan buruan, pemburu dan alat berburu ${ }^{40}$. Demikian juga dalam hukum positif perburuan adalah segala hal yang berkaitan dengan kegiatan berburu yang pembahasannya meliputi satwa buru, pemburu dan alat buru dengan ditambah pembahasan tentang musim dan tempat berburu. ${ }^{41}$ Dengan demikian dapat

${ }^{40}$ Abd ar-Rahman al-Jazairy, Kitab al-Fiqh `ala al-Mazhabi al-'Arba`ah, cet. I (Beirut: Dar al-Fikr, 1996), II: 25

${ }^{41}$ Pasal 1 angka (2) 
dipahami bahwa meskipun secara definisi tidak terlihat persamaannya namun dalam hal pembahasannya terdapat kesamaan yaitu membahas tentang hewan buruan atau satwa buru, pemburu dan alat buru

\section{b) Dari Segi Dasar Hukum}

Hukum Islam dan hukum positif sama-sama menyatakan bahwa berburu merupakan kegiatan yang boleh dilakukan karena sudah merupakan kegiatan manusia yang sudah biasa dilakukan sebagian dari mereka ${ }^{42}$. Selain itu, kebolehan berburu dalam Islam dengan melihat beberapa dalil yang memperbolehkan kegiatan tersebut ${ }^{43}$. Begitu pula dengan hukum positif dapat dilihat pada penjelasan umum yang terdapat pada Peraturan Pemerintah No.13 tahun 1994 tentang Perburuan Satwa Buru yang merupakan dasar hukum bagi kegiatan berburu dalam hukum positif.

\section{c) Dari segi Unsur-unsur Berburu Satwa}

Unsur-unsur berburu sebagaimana yang terdapat dalam hukum Islam meliputi hewan buruan, pemburu dan alat berburu. Hal ini sama dengan pembahasan yang ada dalam hukum positif. Selanjutnya, dalam hukum positif hewan atau satwa yang boleh untuk diburu yaitu hewan liar yang tidak dilindungi ${ }^{44}$ dan dalam hukum Islam hewan yang boleh untuk diburu adalah hewan semua hewan liar kecuali hewan yang haram untuk dimakan ${ }^{45}$. Orang melakukan perburuan haruslah seorang yang sudah balig dan berakal ${ }^{46}$ sementara hukum Positif mensyaratkan seseorang yang ingin mendapatkan akta buru adalah seorang sudah mencapai usia 18 tahun $^{47}$ yang berarti bahwa seorang pemburu haruslah seorang sudah dewasa. Dalam hal

${ }^{42}$ Yusuf al-Qardawi, Halal dan Haram dalam Islam, alih bahasa Mu`ammal Hamidy, (Surabaya: Bina Ilmu, 1982), 82 dan Penjelasan Umum Peraturan Pemerintah No. 13 Tahun 1994 Tentang Perburuan Satwa Buru

${ }^{43}$ Al-Maidah (5): 1, 2, 4, 94, dan 96, sebagai perbandingan lihat juga Imam Muslim, Sahih Muslim, Kitab as-Saidi wa az-Zabaih, (ttp: tp, tt), II: 165. Hadis riwayat dari `Adi ibn Hatim.

\footnotetext{
${ }^{44}$ Pasal 3 ayat (1)

${ }^{45}$ Abd ar-Rahman al-Jazairy, Kitab al-Fiqh, II: 26

${ }^{46}$ Ibid., 28

${ }^{47}$ Pasal 10 ayat (2)
} 
penggunaan alat buru Islam telah mensyaratkan untuk menggunakan senjata yang tajam ${ }^{48}$, berbeda dengan hukum positif, di mana dalam berburu satwa diperbolehkan menggunakan senjata yang telah ditentukan yaitu senjata api, senjata angin dan senjata lainnya yang disesuaikan dengan satwa buru ${ }^{49}$.

\section{d) Dari Segi Sanksi}

Dalam konsepsi fiqh, seorang pemburu apabila hendak berburu haruslah memenuhi syarat yang telah ditetapakan, dan apabila syarat tidak dipenuhi maka hukumnya batal dan hewan buruan pun menjadi haram atau tidak halal (baik untuk dimakan, di jual, dan lain sebagainya). Namun, dalam hukum positif apabila seorang pemburu tidak terlebih dahulu mintak izin pada piaha-pihak yang terkait (pemerintah), maka pemerintah berhak merampas hewan buruan dan senjata buru yang ada pada seorang pemburu. ${ }^{50}$ Dengan demikian hukum Islam dan hukum positif sama-sama mengharuskan akan dipenuhinya syarat-syarat dalam berburu dan apabila syarat-syarat tersebut tidak dipenuhi maka hukumnya batal dan satwa buru tidak bisa dimanfaatkan.

Selain terdapat persamaan, tak dapat dipungkiri bahwa antara Hukum Islam dan Hukum Positif mempunyai beberapa titik perbedaan, yaitu :

\section{a) Dari Segi Pengertian}

Di dalam kitab-kitab fiqh pembahasan tentang perburuan masuk dalam bab الصيد yang sering diartikan dengan buruan atau yang diburu meskipun kata الصيد bisa diartikan sebagai buruan dan perburuan $^{51}$. Sedangkan dalam hukum positif pembahasan perburuan menggunakan istilah perburuan yaitu segala hal yang berkaitan dengan

\footnotetext{
${ }^{48}$ Abd ar-Rahman al-Jazairy, Kitab al-Fiqh, II: 33.

${ }^{49}$ Pasal 9 ayat (1)

${ }^{50}$ KUHP Pasal 52 ayat (2)

51 A.W. Munawwir, Kamus Al-Munawwir Arab-Indonesia Terlengkap, cet. XIV (Surabaya: Pustaka Progressif, 1997), 806
} 
kegiatan berburu. ${ }^{52}$ Dapat diambil contoh; Menangkap ikan dalam hukum Islam termasuk dalam perburuan ${ }^{53}$ sedangkan dalam hukum positif tidak. Kemudian dalam hukum positif mengambil atau memindahkan telur dan sarang satwa buru termasuk dalam perburuan ${ }^{54}$ sedangkan hukum Islam tidak memasukkannya dalam bab perburuan.

\section{b) Dari Segi Dasar Hukum}

Hukum berburu untuk memenuhi kebutuhan hidup dalam hukum Islam adalah halal, tapi apabila berburu untuk tujuan bersenang-senang saja tanpa tujuan untuk memanfaatkannya maka hukumnya makruh ${ }^{55}$. Demikian juga perburuan hukumnya haram apabila pemburu sedang berihram haji ${ }^{56}$. Sedangkan dalam hukum positif perburuan untuk olah raga dan kejuaraan diperbolehkan ${ }^{57}$.

c) Dari segi Unsur-unsur Berburu Satwa

Hukum Islam membagi hewan buruan menjadi dua yaitu hewan air dan hewan darat ${ }^{58}$. Sedangkan hukum positif menjadi tiga yaitu burung, satwa kecil dan satwa besar ${ }^{59}$. Lebih lanjut, hukum Islam juga membagi hewan buruan itu menjadi dua ditinjau dari tujuan berburu yaitu hewan yang diburu untuk dimakan dan tidak untuk dimakan. Hewan yang diburu tidak dimakan pun dibagi menjadi dua; Pertaman, hewan yang diburu untuk melindungi diri dari kejahatan maupun kerusakan seperti menjadi hama, kedua, hewan yang diburu untuk diambil manfaatnya seperti kulit, kuku dan gigi. Demikian juga Hukum positif memperbolehkan berburu untuk mengendalikan hama maupun untuk mengendalikan populasi satwa namun terdapat perbedaan dalam hal yang diperbolehkan untuk berburu.

\footnotetext{
${ }^{52}$ Pasal 1 angka (2)

${ }^{53}$ Al-Maidah (5): 96

${ }^{54}$ Pasal 1 angka (1)

${ }^{55}$ Abu Bakr Jabir al-Jazairy, Minhaj al-Muslim, (Beirut: Dar al-Fikr, 1992), 497

${ }^{56}$ Al-Maidah (5): 96

${ }^{57}$ Pasal 32 ayat (2)

${ }^{58}$ Abu Bakr Jabir al-Jazairy, Minhaj al-Muslim, 497

${ }^{59}$ Pasal 3 ayat (3)
} 
Hukum Islam memperbolehkan siapa saja untuk berburu untuk membasmi hama, sedangkan hukum positif hanya memperbolehkan petugas yang ditunjuk pejabat yang berwenang untuk mengendalikan populasi satwa maupun satwa yang menjadi hama ${ }^{60}$. Selanjutnya hukum Islam memberi beberapa syarat bagi hewan buruan agar halal dimakan $^{61}$. Sedangkan hukum positif membolehkan berburu satwa dengan syarat yaitu liar dan tidak dilindungi ${ }^{62}$. Jadi dalam hukum positif syarat berdasarkan dilindungi atau tidaknya satwa liar bukan dari segi halal haramnya.

Berbicara tentang tempat buru dan musim buru. Hukum Islam tidak membahas tentang tempat buru dan musim buru secara khusus meskipun ada seperti tempat buru boleh di mana saja asal tempat bukan milik seseorang dan hewan buruan bukanlah milik seseorang ${ }^{63}$ demikian juga dengan musim buru. Musim buru yang dilarang untuk berburu yaitu saat ihram atau saat musim haji bagi yang melaksanakan ibadah haji ${ }^{64}$.

Sedangkan hukum positif membagi tempat berburu menjadi tiga yaitu taman buru, kebun buru dan areal buru ${ }^{65}$. Areal buru merupakan kawasan bebas untuk berburu di luar taman buru dan kebun buru $^{66}$. Sedangkan taman buru dan kebun buru adalah tempat berburu yang dapat diusahakan oleh badan usaha yang berbadan hukum yang mempunyai ketentuan-ketentuan, hak dan kewajiban dan masa berakhirnya pengusahaan taman buru dan kebun buru ${ }^{67}$. Kemudian musim buru dalam hukum positif ditentukan berdasarkan pada keadaan

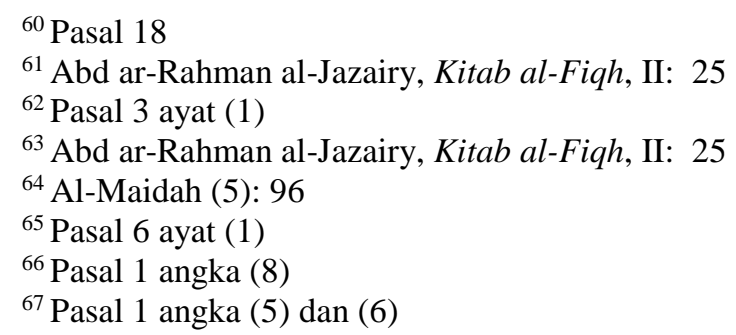


popolasi dan jenis satwa buru, musim kawin, musim beranak atau bertelur, perbandingan jantan dan betina serta umur satwa buru ${ }^{68}$.

Menurut hukum Islam syarat bagi pemburu adalah bahwa ia harus seorang muslim atau ahli kitab, balig dan berakal, berniat dan tasmiyah, tidak sedang ihram dan alat buru harus lepas darinya ${ }^{69}$. Dan bagi hukum positif tidak mensyaratkan seorang pemburu seorang muslim atau bukan berniat dan tasmiyah atau tidak dan diperbolehkan memiliki akta buru apabila telah berusia 18 tahun. ${ }^{70}$

Dalam hal alat buru hukum Islam membaginya menjadi dua yaitu benda dan hewan pemburu ${ }^{71}$. Alat buru benda pun dibagi menjadi dua yaitu benda tajam dan tidak tajam. Benda tajam telah disepakati ulama dalam penggunaannya sedangkan benda yang tidak tajam meskipun ada yang tidak memperbolehkannya namun yang memperbolehkan mengharuskan bahwa benda tersebut dapat melukai dan mengeluarkan darah ${ }^{72}$. Penggunakan hewan pemburu dibolehkan dalam hukum Islam bahkan ditentukan syarat-syaratnya ${ }^{73}$ sedangkan hukum positif melarang berburu menggunakan hewan pelacak ${ }^{74}$.

\section{E. Penutup}

Hukum Islam memandang perburuan sebagai kegiatan manusia yang ada sejak zaman al-Qur`an belum diturunkan sehingga kegiatan itu harus diatur agar manusia mendapatkan yang terbaik dalam hal makanan dan untuk menguji manusia dalam hal ketatan kepada Allah SWT. Demikian juga dalam hukum positif, peraturan Pemerintah No.13 Tahun 1994 tentang Perburuan Satwa Buru menjadi dasar hukum dalam kegiatan berburu di Indonesia. Kemudian di dalam peraturan pemerintah tersebut diatur segala yang berkaitan dengan kegiatan berburu yaitu satwa buru, tempat dan musim buru, alat buru

${ }^{68}$ pasal 7 ayat (2)

${ }^{69}$ Abd ar-Rahman al-Jazairy, Kitab al-Fiqh, II: 29-31

${ }^{70}$ Pasal 10 ayat (2)

${ }^{71}$ Abd ar-Rahman al-Jazairy, Kitab al-Fiqh, II: 33

${ }^{72}$ Ibn Rusyd al-Hafid, Ibn Rusyd al-Hafid, Bidayah al-Mujtahid wa Nihayah al-Muqtasid, (Surabaya: Toko Kitab al-Hidayah, tt), hlm. 333.

${ }^{73}$ Abd ar-Rahman al-Jazairy, Kitab al-Fiqh, II: 35

${ }^{74}$ Pasal 20 ayat (1) huruf (c) 
dan pemburu. Walaupun antara kedua aturan tersebut (hukum Islam dan Hukum Positif) terdapat beberapa perbedaan, namun keduanya juga mempunyai beberapa bentuk persamaan yang menunjukkan bahwa agama (Islam) dan negara ini mempunyai semangat yang sama bahwa satwa merupakan salah satu entitas yang ada di dunia ini yang walaupun dalam beberapa hal boleh dimanfaatkan oleh manusia (makan, menunggangi, dan lain-lain) namun bukan berarti harus dieksploitasi sehingga mengancam eksistensi dan ekosistem dari satwa tersebut. Maka oleh sebab itu lah, dalam konteks Islam manusia sebagai khalifah fil ardh, Islam dengan fiqh-nya dan negara dengan hukumnya, perlu mengatur hal-hal yang berkaitan dengan perburuan satwa demi menjaga siklus kehidupan di dunia ini bisa berjalan seimbang.

\section{DAFTAR PUSTAKA}

Abd ar-Rahman al-Jazairy, Kitab al-Fiqh 'Ala al-Mazahibi al-'Arba'ah, cet. I (Beirut: Daru al-Fikr, 1996)

A.W. Munawwir, Kamus al-Munawwir Arab-Indonesia Terlengkap, cet. XIV (Surabaya: Pustaka Progressif, 1997)

Abu Bakr Jabir al-Jazairy, Minhaj al-Muslim, (Beirut: Dar al-Fikr, 1992)

Departement Agama RI, Al-Qur'an dan Terjemahnya, Surabaya: Surya Cipta Aksara, 1993.

Ibn Rusyd al-Hafid, Bidayah al-Mujtahid wa Nihayah al-Muqtasid, (Surabaya: Toko Kitab al-Hidayah, $\mathrm{tt}$ )

Kansil, C.S.T., Pengantar Ilmu Hukum dan Tata Hukum Indonesia, Jakarta: PN Balai Pustaka, 1984.

Kitab Undang-Undang Hukum Pidana 
Marpaung, Leden, Tindak Pidana Terhadap Hutan, Hasil Hutan dan Satwa, Jakarta: Erlangga, 1995.

Muslim, Sahih Muslim, Kitab as-Saidi wa al-Zabaih, (ttp: tp, tt)

Peter Salim dan Yenny Salim, Kamus Bahasa Indonesia Kontemporer, edisi. 1, (Jakarta: Modern English Press, 1991)

Salim, Peter dan Salim, Yenny, Kamus Bahasa Indonesia Kontemporer, edisi ke-1 Jakarta: Modern English Press, 1991.

Yusuf al-Qardawi, Halal dan Haram dalam Islam, alih bahasa Mu`ammal Hamidy, (Surabaya: Bina Ilmu, 1982)

Peraturan Pemerintah No. 13 Tahun 1994 Tentang Perburuan Satwa Buru, www.menlh.go.id.

Peraturan Pemerintah No. 13 Tahun 1994 tentang perburuan 